\title{
NOTA
}

\section{GOMOSE DA ACÁCIA-NEGRA CAUSADA POR CERATOCYSTIS FIMBRIATA ELL. \& HALST. (')}

\author{
IVAN JOSÉ ANTUNES RIBEIRO $\left({ }^{2}\right)$, MARGARIDA FUMIKO ITO $(2,4)$, \\ OSVALDO PARADELA FILHO $\left({ }^{2}\right)$ e JAIRO LOPES DE CASTRO $\left({ }^{3,4}\right)$
}

\section{RESUMO}

É relatada a ocorrência, pela primeira vez no Brasil, de Ceratocystis fimbriata Ell. \& Halst. sobre acácia-negra. Testes de inoculação cruzada foram efetuados em casa de vegetação com o isolado obtido de acácia-negra (Acacia decurrens Willd.) e outro de mangueira (Mangifera indica L.). Observou-se que ambos os isolados foram patogênicos à acácia-negra e à mangueira.

Termos de indexaçāo: acácia-negra, Acacia decurrens Willd.; Ceratocystis fimbriata Ell. \& Haist.; inoculação cruzada; mangueira, Mangifera indica L.

Ceratocystis fimbriata é um fungo polifago de ampla distribuição geográfica que afeta culturas de elevada importância econômica. Foi constatado em batata-doce, nos EUA (HALSTED, 1890); em cacaueiro, na Guatemala

(1) Trabaiho apresentado no VIII Congresso Paulista de Fitopatologia, realizado em Jaboticabal, 21-23 de janeiro de 1985. Recebido para publicação em 30 de abril e aceito em 26 de outubro de 1987. nas (SP).

(2) Seção de Microbiologia Fitotécnica, Instituto Agronômico (IAC), Caixa Postal 28, 13001 Campi-

(3) Estação Experimental de Capão Bonito (IAC).

$\left({ }^{4}\right)$ Com bolsa de pesquisa do CNPq. 
(SCHIEBER e SOSA, 1960); em cafeeiro, na Colômbia, Venezuela (PONTIS, 1951), Guatemala (SZKOLNIK, 1951) e Costa Rica (ECHANDI e SEGALL, 1956).

No Brasil, já foi constatado sobre crotalária (COSTA, 1935), Cassia fistula (GALLI, 1958), figueira (VALARINI e TOKESHI, 1980), mangueira (ROSSETTO \& RIBEIRO, 1983) e gmelina (RIBEIRO, 1982).

Na região de Capão Bonito, observaram-se numerosas plantas de acácia-negra (Acacia decurrens Willd.) que se apresentavam murchas ou totalmente secas. Seus caules exibiam rachaduras com exsudação de goma e, quando cortados transversalmente, mostravam áreas de coloração cinza-escuro no cerne. Nessas áreas, formavam-se numerosos peritécios do patógeno após uma semana em câmara úmida, os quais foram transferidos assepticamente para o meio de batata-dextrose-ágar (BDA).

Estudaram-se suas características culturais e morfológicas. Naquele meio, o fungo desenvolveu micélio esbranquiçado, que se tornou escuro com o passar do tempo. No início, formavam dois tipos de conídios, os endósporos e artrósporos (VIĖGAS, 1960), após o que havia a formação dos peritécios e clamidósporos. Os peritécios tinham um longo rostro, base globosa, superficial e parcialmente imerso, de coloração negra. $\mathrm{Na}$ extremidade do rostro, formava-se uma pequena gota alaranjada de ascósporos. A cultura do fungo exalava odor característico de fruta madura.

No estudo das características morfológicas, mediram-se as diferentes estruturas do fungo através do micrômetro ocular, efetuando-se cem medições para cada estrutura.

A base do peritécio era escura e envolvida por hifas não diferenciadas com as seguintes médias: $191,91 \mu(149,81-226,49 \mu)$. O rostro era escuro e longo, com $804,60 \mu(560,00-1044,00 \mu)$. As hifas ostiolares eram hialinas e eretas ou divergentes em número de 8 a 13.

O ascósporo era globoso, ovóide, com uma face plana provida de aba e, outra, semelhante a uma calota esférica. Suas medidas médias eram: $6,29 \mathrm{x}$ $4,86 \mu(5,44-7,04 \times 4,32-5,28 \mu)$.

O endósporo era cilíndrico, hialino e unicelular, medindo em média $17,66 \times 6,38 \mu(12,80-22,88 \times 4,80-9,60 \mu)$.

O artrósporo era hialino, maior que o endósporo, com gotas de substância refringente com $27,09 \times 6,01 \mu(14,4-39,68 \times 4,48-7,36 \mu)$ em média.

O clamidósporo era pardo, liso, de parede espessa e grande número central com as seguintes dimensões médias: 13,93 x 9,74 $\mu(11,20-16,16 \times$ $8,32-11,84 \mu)$. 
As características culturais e morfológicas do fungo isolado de acácianegra coincidem com as apresentadas por GALLI (1958), MORGAN-JONES (1967) e VIËGAS (1960) para Ceratocystis fimbriata Ell. \& Halst.

Para o teste de patogenicidade, inocularam-se plantas de acácia-negra com quatro meses de idade, em vasos em casa de vegetação. Através de ferimentos no caule, introduziu-se pequena porção da cultura do fungo, em meio líquido de batata-dextrose, com doze dias de idade. As plantas testemunhas receberam apenas o meio de cultura. Inocularam-se cinco plantas, deixando-se cinco testemunhas. Catorze dias após a inoculação, todas as plantas apresentavam sintomas da doença: delas, foi reisolado o fungo com as mesmas características do inóculo original. As plantas testemunhas permaneceram inalteradas.

Efetuaram-se testes de inoculação cruzada, em casa de vegetação, utilizando-se o isolado de $C$. fimbriata obtido de acácia-negra e outro de mangueira (Mangifera indica $L$.) e plantas de acácia-negra e mangueira com quatro meses de idade. A inoculação foi através de ferimento no caule a $10 \mathrm{~cm}$ do ponteiro da planta, com a introdução de pequena porção da cultura do fungo em BDA, com 15 dias de idade. Efetuaram-se cinco repetiçōes inoculadas e cinco repetições testemunhas para cada isolado e hospedeiro, totalizando 40 vasos, cada vaso com uma planta. Duas semanas após a inoculação, todas as plantas inoculadas apresentavam os ponteiros mortos, enquanto as testemunhas se mantiveram inalteradas.

Concluiu-se que os dois isolados de C. fimbriata apresentam a mesma patogenicidade aos dois hospedeiros testados.

\section{SUMMARY}

\section{GUMMOSIS OF ACACIA DECURRENS WILLD. CAUSED BY CERATOCYSTIS FIMBRIATA ELL. \& HALST.}

Several plants of Acacia decurrens showed wilting and subsequent branche drying. The branches showed wood spliting and gum exudation. The transversally cut wood showed ashy coloured pith, that desenvolved numerous perithecia when kept in a humid chamber. These perithecia were transferred aseptically to potato-dextrose-agar and the culture was classified as Ceratocystis fimbriata Ell. \& Halst. Four mounth old Acacia plants inoculated with the isolate died after 14 days. The fungus was again isolated from these dead plants. Cross inoculation tests with isolate of C. fimbriata from Acacia and mango (Mangifera indica L.) showed pathogenic effects for both hosts.

Index terms Acacia decurrens Willd.; Ceratocystis fimbriata Ell. \& Halst.; cross inoculation; Mangifera indica. 


\section{REFERÊNCIAS BIBLIOGRÁFICAS}

COSTA, A.S. \& KRUG, H.P. Eine durch Ceratostomella hervargerufene Welkekrankheit der Crotalaria juncea in Brasilien, Phytopathologische Zeistschrift, 8:507-513, 1935.

ECHANDI, E. \& SEGALL, R.H. Trunk, branch, and stem canker of coffee trees. Plant Disease Reporter, Beltsville, 40:916-918, 1956.

GALLI, F. Nota sobre a ocorrência de Ceratostomella fimbriata (E. e H.) Elliot em Crotalaria retusa L. e Cassia fistula L. Revista de Agricultura, Piracicaba, 33:225-227, 1958.

HALSTED, B.D. Some fungus diseases of the sweet potato. The black rot. New Jersey, N.J. Agr. Exp. Sta., 1890. 14p. (Bull., 76)

MORGAN-JONES, G. Ceratocystis fimbriata. C.M.I. Descriptions of pathogenic fungi and bacteria, Kew, n. 141, 1967.

PONTIS, R.E. A canker of the coffee tree in Colombia and Venezuela. Phytopathology, St. Paul, 41:178-184, 1951.

RIBEIRO, G.T. Avaliação preliminar da resistência de árvores de Gmelina arborea Lineaus, mediante inoculações do fungo Ceratocystis fimbriata Ell. \& Halst., causador do cancro em gmelina. Fitopatologia Brasileira, Brasília, 7:517, 1982. (Resumo)

ROSSETTO, C.J. \& RIBEIRO, I.J.A. Seca da mangueira. VI. Uma revisão do problema. Ciência e Cultura, São Paulo, 35:1411-1415, 1983.

SCHIEBER, E. \& SOSA, O.N. Cacao canker in Guatemala incited by Ceratocystis fimbriata. Plant Disease Reporter, Beltsville, 44:672, 1960.

SZKOLNIK, M. Coffee trunk and stem canker in Guatemala. Plant Disease Reporter, Beltsville, 35:500-501, 1951.

VALARINI, P.J. \& TOKESHI, H. Ceratocystis fimbriata: agente causal da seca da figueira e seu controle. Summa Phytopathologica, Campinas, 6:102-106, 1980.

VIÈGAS, A.P. Seca da mangueira. Bragantia, Campinas, 19:163-182, 1960. 